\title{
Crowdsourcing indicators for cultural ecosystem services: a geographically weighted approach for mountain landscapes
}

Patrizia Tenerellia ${ }^{\mathrm{a}}$, Urška Demšar ${ }^{\mathrm{b}}$, Sandra Luque ${ }^{\mathrm{a}, \mathrm{c}^{*}}$

*Corresponding author: Sandra.luque@irstea.fr

${ }^{a}$ IRSTEA - National Research Institute of Science and Technology for Environment and Agriculture, UR EMGR Mountain Ecosystems Unit, Grenoble, France Email: patrizia.tenerelli@irstea.fr

${ }^{\mathrm{b}}$ University of St Andrews, School of Geography and Geosciences, North Street, KY16 9AJ St Andrews, Scotland, UK, Email: urska.demsar@st-andrews.ac.uk

${ }^{\mathrm{c}}$ University of St Andrews, School of Biology, St Andrews, Fife KY16 9ST, Scotland UK Email: sandra.luque@irstea.fr

\begin{abstract}
Integrating cultural dimensions into the ecosystem service framework is essential for appraising non-material benefits stemming from different human-environment interactions. This study investigates how the actual provision of cultural services is distributed across the landscape according to spatially varying relationships. The final aim was to analyse how landscape settings are associated to people's preferences and perceptions related to cultural ecosystem services in mountain landscapes. We demonstrated a spatially explicit method based on geo-tagged images from popular social media to assess revealed preferences. A spatially weighted regression showed that specific variables correspond to prominent drivers
\end{abstract}


of cultural ecosystem services at the local scale. The results of this explanatory approach can be used to integrate the cultural service dimension into land planning by taking into account specific benefiting areas and by setting priorities on the ecosystems and landscape characteristics which affect the service supply. We finally concluded that the use of crowdsourced data allows identifying spatial patterns of cultural ecosystem service preferences and their association with landscape settings.

Keywords: non-material ecosystem benefits; cultural service preferences; social perceptions; photoseries analysis; spatially varying relationships; land use planning; recreational choice.

\section{Highlights}

- Revealed preferences of ecosystem service can be acquired from online platforms

- Spatially varying relationships were analysed trough a geographically weighted regression

- Environmental and opportunity settings are locally related to cultural services

- Habitat, accessibility, and view-points have a major impact on the service supply

- Spatial statistical models can be used to identify priority for land use planning

\section{Introduction}

The Ecosystem Service (ES) framework offers an opportunity to capture different dimensions of coupled human-environment systems and integrate natural capital management into decision making and environmental governance. One of the impacts of the growing interest about ES concepts is the improved interdisciplinary component among different academic areas and interest groups (Luck et al., 2012). The category of Cultural Ecosystem Services (CES), in particular, requires assessing benefits and values from different perspectives, 
including socio-ecological (Chan et al., 2012 a, Daniel et al., 2012), socio-cultural (Chiesura and de Groot, 2003, Martín-López et al., 2012, Oteros-Rozas et al., 2014) and psycho-cultural dimensions (Kumar and Kumar, 2008). CES are defined as the non-material benefits that people obtain from ecosystems (MEA 2005). Their intangible and subjective dimensions make CES difficult to quantify and integrate into the ES framework (Daniel et al., 2012, Kirchhoff, 2012), which has led to controversial interpretation and valuation (Chan et al., 2011).

The growing demand for CES (Guo et al. 2010) calls for methods to identify and quantify them in order to plan for the provision of such services. The review work from Milcu et al. (2013) pointed out that CES are least studied among ES, but with an increasing number of publications. Moreover quality indicators for assessing CES are still underdeveloped (Maes et al., 2016, La Rosa et al., 2015, Feld et al., 2009). Assessing and valuing CES allows bridging the gap between ecology, landscape research and social science (Chan et al., 2012 a, Schaich et al., 2010), while promoting a broader perspective of how natural capital contributes to wellbeing. Cultural ES have also played a role in motivating public support for nature conservation (Daniel et al., 2012, Phillips, 1998). Integrated approaches are thus needed to assess non material benefits deriving from CES across several dimensions in order to inform decision-making (Chan et al., 2012) and land planners.

Assessing preferences and benefits of CES is challenging, especially when considering the spatial and temporal dimension. The social demand of CES and nature oriented recreational activities are also fluctuating over space and time (Duffus and Dearden, 1990). Most of the current studies on CES are based on monetary assessment and socio-cultural preferences through interviews or specific surveys which are collected on a declarative basis (e.g. Martín- 
López et al., 2009, Oteros-Rozas et al., 2014, Petrosillo et al., 2007, Vollmer et al., 2015). Revealed preferences for CES are more difficult to capture and spatially referenced data are seldom available. Spatially explicit data on location for nearby CES provision has the potential to reveal specific patterns (Plieninger et al., 2013, Sherrouse et al., 2011, van Berkel and Verburg, 2014) and improve the quality of CES indicators (Hernández-Morcillo et al., 2013). Furthermore spatially explicit indicators can also have a real positive impact in planning contexts and in local decision level (Larosa et. al., 2015).

Several spatial approaches have already been developed to assess and map CES through participatory approaches and surveys (e.g. Bryan et al., 2010, Raymond et al., 2009, van Berkel and Verburg, 2014, Klain et al., 2012 ), biophysical models (e.g. Lautenbach et. al, 2011, Paracchini et al., 2014) or the combination of the two (e.g. Casado-Arzuaga et al., 2014, Kienast et al., 2012, Nahuelhual et al., 2013, Sherrouse et al., 2011) . Spatially explicit models based on the combination of biophysical and socio-cultural variables demonstrated that physical component of landscape can be associated to CES benefit (Plieninger et al., 2013, Sherrouse et al., 2011, van Berkel and Verburg, 2014) and community perception of landscape values (Alessa et al., 2008).

In recent years, following the development of social networks, user generated contents are providing volunteered geographic information (Goodchild, 2007) in different application fields. The very fast rate of image uploading on photo sharing platform, in particular, offers potential for a new map paradigm (Leberl, 2010) defined by a crowd of observers acting as distributed sensors (Singleton, 2010). According to Heipke (2010) images uploaded to a host website can be considered as geospatial data which are crowdsourced by "passive mappers". Those data can be used in mapping tasks after processing and interpretation. Recent studies have used photographs retrieved from online platforms to explore place perception and 
geographical variability of human patterns (Cao and O'Halloran, 2014, Hollenstein and Purves, 2010, Li et al. 2013). The analysis of community contributed photos can also be used as a complementary technique of interviews or questionnaires to assess preferences of CES, assuming that visitors are attracted by the location where they take photographs. Visitor Employed Photography has been employed together with interview by previous studies on landscape and nature perception, proving a suitable way to analyse different environmental aspects which may attract visitors (Dorwart et al., 2009, Taylor et al., 1995). The analysis of photoseries from platforms such as Flickr and Panoramio has already been shown to be a suitable proxy for the empirical estimation of visiting frequency (Da Rugna et al., 2012, Kisilevich et al., 2010, Produit et al., 2014, Sun et al., 2013, Wood et al., 2013). More recently online photo libraries have been used to assess CES (Allan et al., 2015, Arkema at al., 2015, Casalegno et al., 2013, Martínez Pastur et al., 2015, Keeler et al., 2015, Nahuelhual et al., 2013, Richards and Friess, 2015, Willemen et al., 2015).

The primary purpose of this study is to analyse the geographic variability in CES and identify the landscape settings which shape the actual provision of CES. We define the landscape settings as the physical and built characteristics underpinning benefits related to cultural values. The actual provision of CES is given by specific benefiting areas where the service potential supply, or theoretical service provision, match the presence of beneficiaries (Bagstad et al., 2014). Revealed preferences and spatially explicit data of actual service provision were acquired from the online photo-sharing platform Flickr. The number of photographs uploaded on Flickr was used as an indicator to assess a spectrum of opportunities for CES provision in the study area. Our final aim is to understand how landscape settings are spatially associated to people's preferences related to CES in mountain landscapes. The results of this assessment 
finally delivers key information for ecosystem service planning that can help to improve changes at the regional level which directly affect the service delivery.

\section{Materials and methods}

The methodology followed in the present study is based on spatial analysis and modelling of multiple data sources. We divided the workflow into a database preparation phase, an explanatory data analysis and a final interpretation phase (Figure 1).

As a first step we created a database of spatially referenced and validated photoseries. We then selected the landscape settings potentially related to the CES. Specific pre-processing operations for harmonizing the data were performed at this stage. The number of uploaded photographs and the landscape settings were used as dependent and explanatory variables, respectively. In the second phase we performed a local analysis of the factors that contribute to CES at different locations. For this, a global Poisson regression model was compared with a local Geographically Weighted Poisson Regression (GWPR) model in order to see if there exists spatial variability in the relationships between landscape settings and CES. The next sections provide a detailed description of each step.

\section{Figure 1}

\subsection{Study area}

Mountain resources represent important challenges for biodiversity, economic development, place-based cultures and human well-being, while being exceptionally fragile and susceptible 
to rapid changes (MEA 2005). Mountain ES are therefore addressed by an increasing number of publications (Grêt-Regamey et al., 2012). The present study addresses CES in the region of 'Quatre Montagnes' situated in the north of the Vercors massif, at the border between the northern and the southern French Alps (Figure 2). This area is located in the Vercors Natural Regional Park (VNRP), covering 12\% of the extent of the park (25 000 ha), and is part of the Long Term Ecological Research sites (LTER). The area constitutes an important network for nature conservation and biodiversity, encompassing different protection status, such as Natura 2000 areas and Integral Biological Reserves (IBRs). Forest represents the dominant ecosystem, covering $60 \%$ of the landscape; a number of different grasslands habitats also characterize the landscape composition. A variable altitude, ranging from 500 to $2200 \mathrm{~m}$, with very heterogeneous topography, characterizes different types of biota.

The spatial heterogeneity, given by the different lithology, geomorphology, land cover and management practice, results in a complex landscape mosaic which affects ecological processes at different scales (Redon et al., 2014). Within this complex mosaic, the presence of a wide range of natural and semi-natural habitats provides a vast range of ecosystem services. Nature oriented tourism, in particular, is one of the CES which represents a main driver of economic development in the Vercors Mountains. Tourism offer in this area has been increasingly diversified and is characterized by high seasonal fluctuation. In particular, local culture and sense of place related to traditional landscapes are important CES in mountain areas (MEA 2005) such as Quatre Montagne.

The urban and periurban population distributed in the nearby main valleys and the local population of the Quatre Montagnes municipalities -11,865 inhabitants (INSEE, 2007) - are the main beneficiaries of CES in the region. In particular, the urban agglomerate of Grenoble, 
which is in a distance range of about 20 kilometres, the agglomerate of Lyon and the cities of Saint-Etienne, Annecy, Valence and Chambéry, in a distance range of 100 kilometres, represent a significant share of the CES' beneficiaries.

\subsection{Spatial database set-up}

\subsubsection{Creation of the Photoseries database}

For our study area, first the number of photographs uploaded on the two most popular social media sites for online photo sharing, namely Panoramio and Flickr, were compared. The number of photographs uploaded on Flickr was significantly higher (34\% more). Providing the high number of residential population, and the high number of Flickr users in France (Wood et al., 2013), the publication of photographs on Flickr represents a promising opportunity to analyse spatial patterns of visiting frequency and preferences in this area.

The Flickr Application Programming Interface (API) was therefore used to retrieve all the geo-tagged public photographs uploaded from 2012 to 2014 . The geo query was limited to photographs with the most precise recorded accuracy level (street level), this attribute corresponds to the zoom level of the map used to locate the photograph. The total number of returned photographs was 2 176. All photos which were not related to CES and those with an incorrect location were deleted through a systematic visual analytic process based on expert knowledge and multi-media data. The visual analysis allowed identifying different classes of CES related to the following groups specified by the Common International Classification of Ecosystem Services (CICES-V4-3) (Haines-Young and Potschin, 2013): 
i) "Physical and experiential interactions": experiential use and enjoyment of wildlife - represented by photographs of wildlife - and physical use of landscapes photographs of sport and recreational activities, such as skiing, climbing, hiking, camping and others.

ii) "Intellectual and representative interactions": educational activities - represented by photographs of groups of students undertaking nature-related activities -, landscape aesthetics - photographs of natural and anthropic landscapes - and cultural heritage - representation of traditional livestock feeding practices and lifestyle related to agricultural heritage .

The locations of the photos were validated with the support of remote sensing data, virtual globes (Google Earth and Bing Maps) and land use/land cover data, which allowed us to confirm the congruency of the represented physical features (land use/land cover, land form, infrastructure and hydrology). From the original download, a total of 1326 photographs were retained for analysis after the systematic assessment.

Photo count was mapped onto a $250 \mathrm{~m}$ grid to show the spatial distribution of the photos (Figure 2); the maximum number of photos in the cell is 56 , with mean 5 and standard deviation 12 . The $250 \mathrm{~m}$ distance was selected on the basis of the accuracy level of the photo location which depends mainly on the accuracy of the used GPS-enabled devices, or the map scale used to specify the photo location (Hollenstein and Purves, 2010, Li et al., 2013). Different factors, such as image content, world regions (Zielstra and Hochmair, 2013), landscape type (Girardin and Blat, 2007) and popularity of the venue (Hauff, 2013), are also related to the location accuracy. Zielstra and Hochmair (2013) analysed the 2D positional accuracy of Flickr photos for different scene types and different world regions; the authors concluded that the average distance error for all scene types from Flickr in Europe was 58.5 
meters, while the average error for natural panorama photos was 250 meters. Given the complex topography of the study area and the fact that most of the photos are capturing open spaces and panoramic views, we concluded that a $250 \mathrm{~m}$ grid is suitable to represent the photo locations.

\section{Figure 2}

\subsubsection{Explanatory variables selection and processing}

We analysed the landscape settings whose spatial variation may affect the cultural service provision and selected 14 most relevant explanatory variables. The potential explanatory variables were initially chosen based on the literature concerning CES assessment and on expert knowledge of the physical (environmental setting) and infrastructure (opportunity settings) characteristics which are the main drivers of CES provision in the study area.

Some of the variables are proximity indices since attractiveness of landscape feature (sighting points, geology interest points, water bodies and human settlements) and accessibility to facilities (roads and trails, ski resorts, restoration points) decrease with increasing distance. We therefore calculated these indices according to the following modified Gaussian function which estimates the impedance effect of distance (Ingram, 1971):

$E_{j}=\frac{\sum_{i=1}^{n} \exp \frac{-d^{2}}{2 c^{2}}}{n}$

where $E$ is the proximity index for cell $j, d$ is Euclidean distance (m) from the photo location to the nearest feature, $c$ is the standard deviation of distance values - ranging from 50 to $150 \mathrm{~m}$ according to the feature type -, and $n_{i}$ is number of photos within the $j$ cell. 
All continuous variables other than proximity were calculated according to the following function:

$V_{j}=\frac{\sum_{i=1}^{n} v}{n}$

where $V_{j}$ is the average cell value, $v$ is the bilinear interpolation of the cell values adjacent to the photo location and $n_{i}$ is the number of photos within the $j$ cell.

The selected explanatory variables were categorized into two different types: environmental variables and opportunity setting variables. In the rest of this section we provide details on variable selection methodology, including a detailed description and mathematical derivation of variables and the correlation analysis.

\section{Potential environmental variables}

A set of 9 environmental variables was selected for our model (Table 1). The presence of water bodies and hydrology is one of the most used variable in CES and recreational choice models ( Bestard and Font, 2009, Casado-Arzuaga et al., 2014, Colson et al., 2010, Kienast et al., 2012, Paracchini et al., 2014, Nahuelhual et al., 2013, Zandersen et al., 2007). The proximity to lakes and streams was therefore included in our model. Protection status is also used by many authors as a proxy to assess the cultural value of an ecosystem (CasadoArzuaga et al., 2014, Colson et al., 2010, Nahuelhual et al., 2013, Paracchini et al., 2014, Raudsepp-Hearne et al., 2010). We created a protection status index by ranking and summing different protection status present in the study area, as explained in Table 1. We selected also 
the main habitats types related to CES benefits (Martínez Pastur et al., 2015, Richards and Friess, 2015) as well as habitat diversity (Fuller et al., 2007, Kienast et al., 2012, Richards and Friess, 2015) as main habitat attributes. Different terrain variables were selected, including: i) view points and summits (Casado-Arzuaga et al., 2014, Kienast et al., 2012, Termansen et al., 2004, Zandersen et al., 2007); ii) slope (Bestard and Font, 2009, Colson et al., 2010, Kienast et al., 2012, Zandersen et al., 2007); iii) elevation (Bestard and Font, 2009, Casado-Arzuaga et al., 2014). Other selected variables related to environmental settings included insolation (Kienast et al., 2012) and presence of geological interest points (Casado-Arzuaga et al., 2014, Nahuelhual et al., 2013).

\section{Potential Opportunity setting variables}

The opportunity setting variables were included in the model to take into account the infrastructures and the potential demand which are related to the CES. A total of 5 variables were selected (Table 1). Accessibility and the presence of hiking trails is used as the main infrastructure influencing the cultural service supply (Casado-Arzuaga et al., 2014, Kineast et. al., 2012, Nahuelhual et al., 2013, Paracchini et al., 2014, Richards and Friess, 2015). We therefore used proximity to roads, including forest roads and trails, as an indicator that was translated into accessibility to CES. We supported this assumption in Zandersen et al. (2007) that used travel distance in his CES model. In the present study, we then represented the potential demand of the service as the number of people who can reach each location from the surrounding $100 \mathrm{~km}$ calculated trough the cost function described in Table 1. Finally we selected the presence of climbing sites (Casado-Arzuaga et al., 2014), the presence of restoration points (Bestard and Font, 2009), the presence of built-up areas (Colson et al., 2010, Kienast et al., 2012, Martínez Pastur et al., 2015) and the presence of ski resort (Colson et al., 2010). 


\section{Table 1}

\section{Final explanatory variables}

The collinearity of the global variables was assessed using Spearman's correlation rank (Table 2). All the variables were retained as they showed a Spearman's correlation lower than 0.7, except for proximity to settlements (Settl) and the average altitude (Alti) which are considered to be significantly correlated with each other and with the number of people who can access a cell from the surrounding cells (Pop). A final set of 12 variables was thus obtained. All variables are continuous, except the habitat class which is a nominal variable.

\section{Table 2}

\subsection{Geographically weighted regression for cultural ecosystem services}

\subsubsection{Global vs local regression model}

To investigate the presence of the spatial variability in the relationships between the dependent variable (photo count) and the explanatory variables (landscape settings), we employed a spatial statistical approach using Geographically Weighted Regression (GWR, Fotheringham et al. 2002). Standard statistical methods, such as global regression, assume the same relationship happening likewise everywhere in the space and thus produce an averaged global value that is valid for the entire data set, but may in fact not be valid anywhere. Yet, these standard methods fail capturing the spatial variability that is one of the main attributes to explain local differences. Henceforth, local methods, such as GWR, resolve this problem by calibrating a separate model at each location, taking into account only the data from the 
nearest neighbourhood of the calibration point. These data are additionally weighted according to the geographic distance from each data point to the calibration point in such a way that data closer to the calibration point are given more importance than data further away. The result is a set of local models, one at each point, which capture any spatial variability in the relationships.

Many studies have applied GWR in human and political geography (e.g. Mansley and Demšar, 2015, Brunsdon et al., 1996, Fotheringham et al., 2013), as well as physical geography and ecology (e.g. Atkinson et al., 2003, Clement et al., 2009, Harris et al., 2010, Jetz et al., 2005), proving the suitability of this tool to provide an explanatory approach in spatially varying relationships (Páez et al., 2011). Geographical weighting can be applied to many different types of models, including different regression types. In the present study, the dependent variable is the count of photos in each grid cell. This number can never be negative, therefore the function used in regression model needs to be a function that is not able to produce negative output. For count variables, typically a Poisson function is used, which models the relationship between the dependent variable and independent variables using an exponential function (which can never be negative). We further take a local (that is, a geographically weighted) version of this model, to investigate the presence and level of any potential spatial variability. In this subsection we describe the methodology for our GW Poisson regression modelling including the model building procedure and procedure for interpretation of results. We calibrated the models using the GWR4 software (Nakaya et al., 2005). 


\subsubsection{Geographically Weighted Poisson Regression}

Given the high diversity of habitats and ecosystems in the study area, we assume that CES deliver is context-specific and we expect a significant geographical variation in the relations between the photo count and explanatory variables. A local statistical model was therefore applied to identify any spatial variability that may exist in the relationship. For this we used a Geographically Weighted Poisson Regression (GWPR) (Fotheringham et al., 2002), which is a spatial version of a global Poisson regression and takes into account geographic proximity of data points through a weighting kernel function. A GWPR can be expressed as:

$y_{i} \sim \operatorname{Poisson}\left[e^{\left(\sum_{n} \beta_{n, i} x_{n, i}\right)}\right]$

where $y_{i}$ is the estimated value of the dependent variable at the cell $i, \beta_{n, i}$ is the parameter estimate for variable $n$ at the cell $i$, and $x_{n, i}$ is the $n$th independent variable at the cell $i$. That is, instead of building one global regression model that would attempt to describe the relationship between the photo count and the independent variables (i.e. with one single equation and one global parameter for each independent variable), we built a set of local Poisson models, one in each $i$ th grid cell. This means that instead of having one global model, we have a model for each location and the model parameters, instead of being constant values, build a surface for each independent variable.

Further, each of these models is calibrated on a geographically weighted subset of data: we take a subset of data points around each location and assign a weight to each of these points based on the distance from the calibration location to the respective data point. For this we use a spatial kernel function, which is some kind of an inverse bell-function (e.g. Gaussian or bisquare) with a maximum value at the calibration point and which is decreasing radially on all sides from the calibration point. This kernel function is used to assign a weight to each data 
point based on the distance from the calibration point to the data point. The cut-off for this distance, called the bandwidth, correspond to the size of the spatial kernel and is given as either a distance cut-off (for the co-called fixed weighting) or a number of neighbouring data points considered in the weighting (for the so-called adaptive weighting) (Fotheringham et al. 2002). We used an adaptive bi-square kernel, the size of which was calibrated based on the data through the optimisation of the Akaike Information Criterion AICc (Fotheringham et al., 2002). The adaptive kernel includes the same number of points at each location, thus allowing a varying kernel size, and it is suitable for data with large density variation (Nakaya et al., 2005). The bi-square function excludes the points outside the selected radius (Brunsdon et al., 1996).

\subsubsection{Geographical variability test and comparison of models}

Spatial variability, at times, is only present in a subset of relationships between the dependent variable and explanatory variables. This means that some of these relationships do vary over space, but others may not, i.e. they are global. In such cases, instead of building a fully local or a fully global model, a semi-parametric model is a better choice, that is, a model that considers some of the variables global and others as local (Fotheringham et al. 2002). In our case, a geographical variability test was run to check for the spatial variability of each parameter estimate and to identify which of the selected variables vary over space (local to global approach). This test compares a GWPR model where all variables are assumed to vary spatially with different semi-parametric models, in which only one of the variables is fixed (a global variable) while the others are kept as local. Once the local and global variables are identified, the semi-parametric model (Nakaya et al., 2005) can be expressed as:

$$
y_{i} \sim \operatorname{Poisson}\left[N_{i} e^{\left(\sum_{n} \beta_{n, i} x_{n, i}\right)+\sum_{m} \alpha_{m} x_{m, i}}\right]
$$


where $x_{m, i}$ is the $m$ th independent variable with a coefficient $\alpha_{m}$ which is assumed not to be dependent on geographical location.

\subsubsection{GWPR interpretation}

The first step in the interpretation of the GWPR results was to compare the quality for the semi-parametric GWPR model with the global Poisson regression model to assess whether it improved the regression. For this we used two measures, the corrected Akaike Information Criterion (AICc) and the percentage of deviance explained by the model (Fotheringham et al. 2002). If spatial variability is present, the local model should show a lower version of the AICc and a higher percentage of deviance.

Once we calibrated our local model, the spatial variability in the relationships was evaluated trough a visual representation of the parameter estimate surfaces. These were cross-mapped with the local z-values for each parameter estimate to identify areas where the relationships are significant. The local percentage of explained deviance was also mapped in order to identify areas were the model is performing better (percentage of explained deviance higher than the average) or worse, and to relate these patterns with the most significant local parameter estimates.

Finally we tested the spatial distribution of the local and global residuals both trough a visual representation and using Moran's I measure of spatial autocorrelation. Mapping residuals and calculating the level of their spatial autocorrelation is a way to confirm the presence of spatial variability. Residuals are defined as the difference between the real value and the predicted value at each location. For a global model, if spatial variability is present, this means that 
locations that are close to each other will have similar residual values and therefore there will be a high level of spatial autocorrelation present in residuals. In local modelling however, since each local model is fit to the nearest neighbourhood of each point, the residuals should be less spatially autocorrelated. The level of spatial autocorrelation can be investigated visually by mapping the standardised residuals for both models as well as calculating measures of spatial autocorrelation, such as e.g. Moran's I (Goodchild, 1986, Moran, 1950). This is a standard spatial analysis measure, which provides the information needed on the level of autocorrelation as well as on its statistical significance.

\section{Results}

\subsection{GWPR and geographical variability test}

The first step in the GWPR procedure is to fit a global model to the data. Table 3 presents the result of the global Poisson model which explained 13\% of deviance, with an AICc coefficient of 1111.6133 . The result of the global regression suggest that only 4 parameter estimates are significant, and that the proximity to sighting points and the dominant habitat type are the most significant parameters.

In the next step we first built a fully local GWPR model. For this, the result of the bandwidth optimisation suggested an optimal bandwidth of 102 cells (i.e. for each of the 415 cells, a local model was calibrated using data from the nearest 102 cells). The model fit was much improved from the local model with an average $56 \%$ of deviance explained and with an AICc equal to 816.3856 (i.e. a large decrease from the global model). This improvement of the 
model quality from global to local shows that there is indeed spatial variability present in the data that is important to disentangle.

In order to improve the model even further and account for different variables having a local or a global profile, we ran the geographical variability test. This test showed that the spatial variation was significant for all variables, except for the proximity to restoration points (Rest) which is better related to the CES at the global level. However, it must be noted that when we calibrated a semiparametric GWPR model with Rest as a global variable, setting all remaining variables to vary locally, this did not improve the model (average 38\% deviance explained). We therefore selected the full local GWPR as our final model that explained best the varying relations between the photo count and the selected variables.

\section{Table 3}

\subsection{Parameter estimate surfaces}

In order to interpret the spatial relationships resulting from GWPR, we represented the local parameter estimate surfaces and we analysed the spatial distribution of their significance level (Figure 3). To do so we represented only the values which are statistically significant at 95\% confidence interval (local z-values less than -1.96 or more than 1.96), while grid cells where relationships are not significant are shown as white. In general, the parameters are not significant in the central part of Quatre-Montagnes, except for a few locations where the habitat parameters (Hab and Landiv) and accessibility are significant. It can be observed that there are two distinct areas, north and central part of the study area, where both the parameters that are related to the habitat (dominant habitat and habitat diversity) are significant. Another 
trend can be observed for the two terrain parameters (slope and presence of viewpoints) which are more significant on the eastern border of the study area, which is characterized by the highest altitude values. The most significant parameters in terms of covered surface are: dominant habitat, accessibility, diversity of habitat and proximity to view points; all of them being significant in more than $50 \%$ of the cells. The least significant parameters are: proximity to geology interest points, proximity to restoration points and number of people who can reach the cell, which are significant in $14 \%, 20 \%$ and $20 \%$ of the cells, respectively. The results obtained are in accordance with the global model, with the exception of the diversity of habitat which is not a significant variable at the global level, but it is significant in $61 \%$ of locations in the local model.

\section{Figure 3}

\subsection{Local percentage deviance explained}

In order to analyse the local variability of the relationships between the photo count and the explanatory variables we also mapped the local percentage of explained deviance. Figure 4 presents the explained deviance, showing that is everywhere higher than in the global model. We could identify two spatial clusters (see clusters 1 and 2) where the percentage of deviance explained is higher than average and three clusters (see clusters $3,4,5$ ) where the percentage of deviance explained is lower than the average (Figure 4). In Table 4 we related the percentage of explained deviance to the significant parameters for each cluster. In clusters 1 and 2 , the two habitat parameters are significant in more than $50 \%$ of cells. Moreover in cluster 1 - northwest of the study area - the accessibility is significant everywhere and the proximity to sky resorts showed significant values in more than $50 \%$ of cells. In cluster number 2 - central-eastern part of the study area - all the variables, with the only exception of the proximity to water bodies and the proximity to geology interest point, are significant in 
the local model and most of them are significant in more than $50 \%$ of the locations. All the clusters where the percentage of deviance explained is lower than the average are characterized by a smaller set of significant parameters. In particular, in cluster 3 - central part of the study area - there is a small percentage of cells where a few parameters are significant.

\section{Figure 4}

\section{Table 4}

\subsection{Analysis of local and global residuals}

The presence of spatial variability was confirmed by the spatial distribution of residuals. As expected, residuals from the global model have a higher level of spatial autocorrelation than the local model, which is visually seen as each cell having more cells of the same colour in the global residuals map than in the local residuals map (Figure 5). This is confirmed by spatial autocorrelation scores (Table 5). The z-score of the Moran's I analysis is in fact suggesting that the spatial clustering of the residuals is statistically significant to the 0.10 level in the global model, while the local model present a more random spatial distribution of residual values. The higher autocorrelation of the residuals in the global model vs. the local model confirms that the relationship between the photo count and the explanatory variables is a spatially varying process.

In residual modelling, it is also of interest to ask where the residuals are large, meaning that the model is not performing well in those locations, which can lead to further investigation 
into why these locations are different from the rest in terms of CES. We therefore analysed the locations where the local standard residuals are high (more than 2.58, meaning that they are outside of the $99 \%$ confidence interval). We analysed the photo content in these particular locations and we found out that they correspond to landscape features which are special or extraordinary. In particular the cell represented with number 8 in Figure 5-b is characterize by the presence of a waterfall (Cascade de la Fauge) where a high number of photos are uploaded. The same stands for number 9, that corresponds to an historical site (Les ruines de Valchevrière) which represent a unique cultural heritage in the area; while number 1 correspond to the old Olympic trampoline situated in a very panoramic location. All the other identified cells correspond to exceptional panoramic view points characterized by very wide view-sheds.

\section{Table 5}

Figure 5

\section{Discussion}

Results of the spatial analysis of photo series indicate specific patterns of visiting preferences and how CES are associated with environmental settings at different scales of analysis. The spatial distribution of visiting preferences provides an indicator of the experiential benefits of CES, allowing a local analysis of service providing areas and addressing the lack of quantitative indicators of CES (Maes et al., 2016, La Rosa et al. 2015).

Our explanatory analysis allows the identification of focus areas where land use planning and ecosystem management strategies should take into account the actual provision of nonmaterial benefit related to ES. The analysis performed support the setting of landscape planning priorities by providing an understanding on how changes in certain environmental settings may affect the CES supply in specific areas. Hence, the proposed method provides an 
important first step to inform stakeholders and policy makers on priority areas. This work could be followed by location-based interviews or questionnaires which would allow assessing the benefit and different values related to CES (Fürst et al 2014).

However the identified areas are indicative considering that i) the boundary are arbitrarily defined; ii) the patterns of CES provision and the people preferences are dynamic over time; iii) people attitude to take photographs changes with the different recreation activities (Wood et al., 2013): certain activities can be less represented - as an example rock climbers may take less photos than people having a picnic -; iv) the photo-sharing community may not be representative of specific community groups: the represented population will be dependent on the level of access to information technology, so education and age, and the user's ability/willingness to correctly assign geo-tags to the photos. In that sense, Li et al. (2013) and Girardin et al (2008) suggested that well-educated people are more likely to contribute to photo-sharing platforms and that further psychological and sociological research are needed to explain the behaviour of social media users. Other limitations of this method are related to the difficulty to obtain information related to the user characteristics which could reveal significant correlation with the photo content. Nevertheless, it should be considered that stated preference methods undertaken through traditional surveys and interviews are also biased by the composition of the reference group and the inherent vagueness of declared visiting preferences due to the conceptualization of geographic space (Hollenstein and Purves, 2010). Despite the above mentioned limitations spatially referenced data collected through popular photo-sharing platforms provide a low cost indicator for mapping the actual CES provision which is difficult to obtain in a rapid and cost-effective way through traditional data gathering techniques. 
To be noted, that the socio and psycho-cultural aspects of the CES provision go beyond the scope of this study; nevertheless those issues are crucial in order to define different values related to the services from the point of view of individuals and society at large. Further research is therefore needed to take into account different dimensions which are related to values hold by individuals and groups and cannot be explained by ecosystem components alone.

\section{Concluding remarks}

Compared to conventional multivariate model, which can hide local conditions, geographical weighted regression provides a valuable technique for spatial explanatory data analysis. In the present study a geographical weighted Poisson regression revealed significant spatial variability in the relation between landscape settings and CES. The method succeeded to capture spatial fluctuations that explain important preferences. Moreover this explanatory analysis allowed identifying locations where specific variables correspond to prominent drivers of CES.

In the central, south-east and south-west sections of the study area, the relations are less evident. In all, dominant habitat, accessibility, diversity of habitat and proximity to view points were identified as the variables having a major impact on CES. The fact that in certain locations the association between landscape settings and CES is not significant suggests that other paradigms, such as the cognitive and socio-cultural ones, should be considered to understand specific relations between CES benefit and environmental variables. Ultimately, the method allows disentangling local relationships that exist between the spatial distribution of different biophysical factors and cultural ecosystem services. All in all, the novelty of the approach is not just assessing cultural ecosystem services but identifying the key landscape 
features and their spatial location that have an importance for their provision at local and regional scales, highlighting the importance of capturing the spatial variability in the analysis.

The potential of crowdsourcing geospatial data is growing with the advances in web technology and the emergent accessibility to internet and mobile devices, allowing the acquisition of an increasing amount of worldwide distributed data which would have been unthinkable until recently. This study demonstrates the applicability of this novel data source in the CES domain. We envisage a growing research interest on the processing and interpretation of crowdsourced data which will contribute to the operationalization of this rapid and cost-effective method for mapping CES.

\section{Acknowledgements}

This work was partially supported by the OpenNESS project funded from the European Union's Seventh Programme for research, technological development and demonstration under grant agreement $\mathrm{n}^{\circ} 308428$. The authors are solely responsible for the content of this publication. It does not represent the opinion of the European Union, nor is the European Union responsible for any use that might be made of information appearing herein.

\section{References}

Alessa, L. N., Kliskey, A. A., \& Brown, G. (2008). Social-ecological hotspots mapping: A spatial approach for identifying coupled social-ecological space. Landscape and Urban Planning, 85(1), 27-39. http://doi.org/10.1016/j.landurbplan.2007.09.007 Allan, J. D., Smith, S. D., McIntyre, P. B., Joseph, C. A., Dickinson, C. E., Marino, A. L., ... \& Adeyemo, A. O. (2015). Using cultural ecosystem services to inform restoration priorities in the 
Laurentian Great Lakes. Frontiers in Ecology and the Environment, 13(8), 418-424. http://doi.org/10.1890/140328

Arkema, K. K., Verutes, G. M., Wood, S. A., Clarke-Samuels, C., Rosado, S., Canto, M., ... \& Guerry, A.D. (2015). Embedding ecosystem services in coastal planning leads to better outcomes for people and nature. Proceedings of the National Academy of Sciences, 112(24), 7390-7395.

Atkinson, P. M., German, S. E., Sear, D. A., \& Clark, M. J. (2003). Exploring the relations between riverbank erosion and geomorphological controls using geographically weighted logistic regression. Geographical Analysis, 35(1), 58-82.

Bagstad, K. J., Villa, F., Batker, D., Harrison-Cox, J., Voigt, B., \& Johnson, G. W. (2014). From theoretical to actual ecosystem services: Mapping beneficiaries and spatial flows in ecosystem service assessments. Ecology and Society, 19(2), 64.

Bastian, O., Grunewald, K., Syrbe, R.-U., Walz, U., \& Wende, W. (2014). Landscape services: the concept and its practical relevance. Landscape Ecology, 29(9), 14631479. http://doi.org/10.1007/s10980-014-0064-5

Brunsdon, C., Fotheringham, A. S., \& Charlton, M. E. (1996). Geographically Weighted Regression: A Method for Exploring Spatial Nonstationarity. Geographical Analysis, 28(4), 281-298. http://doi.org/10.1111/j.1538-4632.1996.tb00936.x

Bryan, B. A., Raymond, C. M., Crossman, N. D., \& Macdonald, D. H. (2010). Targeting the management of ecosystem services based on social values: Where, what, and how? Landscape and Urban Planning, 97(2), 111-122. http://doi.org/10.1016/j.landurbplan.2010.05.002

Cao, Y., \& O'Halloran, K. (2014). Learning human photo shooting patterns from large-scale community photo collections. Multimedia Tools and Applications. http://doi.org/10.1007/s11042-014-2247-0 
Casado-Arzuaga, I., Onaindia, M., Madariaga, I., \& Verburg, P. H. (2014). Mapping recreation and aesthetic value of ecosystems in the Bilbao Metropolitan Greenbelt (northern Spain) to support landscape planning. Landscape Ecology, 29(8), 13931405. http://doi.org/10.1007/s10980-013-9945-2

Casalegno, S., Inger, R., DeSilvey, C., \& Gaston, K. J. (2013). Spatial Covariance between Aesthetic Value \&amp; Other Ecosystem Services. PLoS ONE, 8(6), e68437. http://doi.org/10.1371/journal.pone.0068437

Chan, K. M. A., Satterfield, T., \& Goldstein, J. (2012). Rethinking ecosystem services to better address and navigate cultural values. Ecological Economics, 74, 8-18. http://doi.org/10.1016/j.ecolecon.2011.11.011

Chiesura, A., \& de Groot, R. (2003). Critical natural capital: a socio-cultural perspective. Ecological Economics, 44(2-3), 219-231. http://doi.org/10.1016/S09218009(02)00275-6

Clement, F., Orange, D., Williams, M., Mulley, C., \& Epprecht, M. (2009). Drivers of afforestation in Northern Vietnam: Assessing local variations using geographically weighted regression. Applied Geography, 29(4), 561-576. http://doi.org/10.1016/j.apgeog.2009.01.003

Colson, V., Garcia, S., Rondeux, J., \& Lejeune, P. (2010). Map and determinants of woodlands visiting in Wallonia. Urban Forestry \& Urban Greening, 9(2), 83-91. http://doi.org/10.1016/j.ufug.2009.04.002

Daniel, T. C., Muhar, A., Arnberger, A., Aznar, O., Boyd, J. W., Chan, K. M. A., ... \& von der Dunk, A. (2012). Contributions of cultural services to the ecosystem services agenda. Proceedings of the National Academy of Sciences, 109(23), 8812-8819. http://doi.org/10.1073/pnas.1114773109 
Da Rugna, J., Chareyron, G., \& Branchet, B. (2012). Tourist behaviour analysis through geotagged photographies: a method to identify the country of origin. In Computational Intelligence and Informatics (CINTI), 2012 IEEE 13th International Symposium on (pp. 347-351). IEEE. Retrieved from http://ieeexplore.ieee.org/xpls/abs_all.jsp?arnumber=6496788

Dorwart, C. E., Moore, R. L., \& Leung, Y.-F. (2009). Visitors' Perceptions of a Trail Environment and Effects on Experiences: A Model for Nature-Based Recreation Experiences. Leisure Sciences, 32(1), 33-54.

http://doi.org/10.1080/01490400903430863

Duffus, D. A., \& Dearden, P. (1990). Non-consumptive wildlife-oriented recreation: A conceptual framework. Biological Conservation, 53(3), 213-231. http://doi.org/10.1016/0006-3207(90)90087-6

Feld, C. K., Martins da Silva, P., Paulo Sousa, J., de Bello, F., Bugter, R., Grandin, U., ... \& Harrison, P. (2009). Indicators of biodiversity and ecosystem services: a synthesis across ecosystems and spatial scales. Oikos, 118(12), 1862-1871. http://doi.org/10.1111/j.1600-0706.2009.17860.x

Fotheringham, A. S., Brunsdon, C., \& Charlton, M. (2002). Geographically weighted regression: the analysis of spatially varying relationships. Chichester, England; Hoboken, NJ, USA: Wiley.

Fotheringham, A. S., Kelly, M. H., \& Charlton, M. (2013). The demographic impacts of the Irish famine: towards a greater geographical understanding: The demographic impacts of the Irish famine. Transactions of the Institute of British Geographers, 38(2), 221237. http://doi.org/10.1111/j.1475-5661.2012.00517.x 
Fuller, R. A., Irvine, K. N., Devine-Wright, P., Warren, P. H., \& Gaston, K. J. (2007).

Psychological benefits of greenspace increase with biodiversity. Biology Letters, 3(4), 390-394. http://doi.org/10.1098/rsbl.2007.0149

Fürst, C., Opdam, P., Inostroza, L., \& Luque, S. (2014). A balance score card tool for assessing how successful the ecosystem services concept is applied in participatory land use planning. Landscape Ecology 29(8), pp. 1435-1446

Girardin, F., \& Blat, J. (2007). Place this photo on a map: A study of explicit disclosure of location information. Late Breaking Result at Ubicomp. Retrieved from http://citeseerx.ist.psu.edu/viewdoc/download?doi=10.1.1.105.9589\&rep=rep1\&type= pdf

Girardin, F., Fiore, F. D., Ratti, C., \& Blat, J. (2008). Leveraging explicitly disclosed location information to understand tourist dynamics: a case study. Journal of Location Based Services, 2(1), 41-56.

Goodchild, M. F. (1986). Spatial autocorrelation. Norwich: Geo Books.

Goodchild, M. F. (2007). Citizens as sensors: the world of volunteered geography. GeoJournal, 69(4), 211-221. http://doi.org/10.1007/s10708-007-9111-y

Grêt-Regamey, A., Brunner, S. H., \& Kienast, F. (2012). Mountain Ecosystem Services: Who Cares? Mountain Research and Development, 32(S1), S23-S34. http://doi.org/10.1659/MRD-JOURNAL-D-10-00115.S1

Guo, Z., Zhang, L., \& Li, Y. (2010). Increased dependence of humans on ecosystem services and biodiversity. PLoS One, 5(10), e13113.

Harris, P., Fotheringham, A. S., \& Juggins, S. (2010). Robust Geographically Weighted Regression: A Technique for Quantifying Spatial Relationships Between Freshwater Acidification Critical Loads and Catchment Attributes. Annals of the Association of American Geographers, 100(2), 286-306. http://doi.org/10.1080/00045600903550378 
Haines-Young, R., \& Potschin, M. (2013). Common International Classification of Ecosystem Services (CICES): Consultation on Version 4, August-December2012.Report to the European Environment Agency. Revised January 2013. Retrieved from http://cices.eu/resources/

Hauff, C. (2013). A study on the accuracy of Flickr's geotag data. In Proceedings of the 36th international ACM SIGIR conference on Research and development in information retrieval (pp. 1037-1040). ACM. Retrieved from http://dl.acm.org/citation.cfm?id=2484154

Heipke, C. (2010). Crowdsourcing geospatial data. ISPRS Journal of Photogrammetry and Remote Sensing, 65(6), 550-557. http://doi.org/10.1016/j.isprsjprs.2010.06.005

Hernández-Morcillo, M., Plieninger, T., \& Bieling, C. (2013). An empirical review of cultural ecosystem service indicators. Ecological Indicators, 29, 434-444. http://doi.org/10.1016/j.ecolind.2013.01.013

Hollenstein, L., \& Purves, R. (2010). Exploring place through user-generated content: Using Flickr to describe city cores. Journal of Spatial Information Science, (1). http://doi.org/10.5311/JOSIS.2010.1.3

Ingram, D. R. (1971). The concept of accessibility: A search for an operational form. Regional Studies, 5(2), 101-107. http://doi.org/10.1080/09595237100185131 Institut national de la statistique et des études économiques (INSEE)(2007).Estimations carroyées de population (ECP) $1 \mathrm{~km}$ - revenus fiscaux localisés (RFL). Copyright 2007, INSEE.

Institut National de l'Information Géographique et Forestière (IGN)(2008).BD TOPO. Copyright 2008, IGN.

Institut National de l'Information Géographique et Forestière (IGN)(2009). BD ALTI 25m. Copyright 2009, IGN. 
Irstea (2014). BD Stations. https://forge.irstea.fr/projects/bd_stations (accessed 07.11.14).

Jetz, W., Rahbek, C., \& Lichstein, J. W. (2005). Local and global approaches to spatial data analysis in ecology. Global Ecology and Biogeography, 14(1), 97-98.Keeler, B. L., Wood, S. A., Polasky, S., Kling, C., Filstrup, C. T., \& Downing, J. A. (2015). Recreational demand for clean water: evidence from geotagged photographs by visitors to lakes. Frontiers in Ecology and the Environment, 13(2), 76-81. http://doi.org/10.1890/140124

Kienast, F., Degenhardt, B., Weilenmann, B., Wäger, Y., \& Buchecker, M. (2012). GISassisted mapping of landscape suitability for nearby recreation. Landscape and Urban Planning, 105(4), 385-399. http://doi.org/10.1016/j.landurbplan.2012.01.015

Kirchhoff, T. (2012). Pivotal cultural values of nature cannot be integrated into the ecosystem services framework. Agenda, 109, 8812-8819.

Kisilevich, S., Krstajic, M., Keim, D., Andrienko, N., \& Andrienko, G. (2010). Event-Based Analysis of People's Activities and Behavior Using Flickr and Panoramio Geotagged Photo Collections (pp. 289-296). IEEE. http://doi.org/10.1109/IV.2010.94

Klain, S. C., \& Chan, K. M. A. (2012). Navigating coastal values: Participatory mapping of ecosystem services for spatial planning. Ecological Economics, 82, 104-113. http://doi.org/10.1016/j.ecolecon.2012.07.008

Kumar, M., \& Kumar, P. (2008). Valuation of the ecosystem services: A psycho-cultural perspective. Ecological Economics, 64(4), 808-819. http://doi.org/10.1016/j.ecolecon.2007.05.008

La Rosa, D., Spyra, M., \& Inostroza, L. (2015). Indicators of Cultural Ecosystem Services for urban planning: A review. Ecological Indicators. http://doi.org/10.1016/j.ecolind.2015.04.028Lautenbach, S., Kugel, C., Lausch, A., \& Seppelt, R. (2011). Analysis of historic changes in regional ecosystem service 
provisioning using land use data. Ecological Indicators, 11(2), 676-687.

http://doi.org/10.1016/j.ecolind.2010.09.007

Leberl, F. (2010). Time for Neo-Photogrammetry. GIS Development, 14 (2), 22-24.

Li, L., Goodchild, M. F., \& Xu, B. (2013). Spatial, temporal, and socioeconomic patterns in the use of Twitter and Flickr. Cartography and Geographic Information Science, 40(2), 61-77. http://doi.org/10.1080/15230406.2013.777139

Luck, G. W., Chan, K. M. A., Eser, U., Gómez-Baggethun, E., Matzdorf, B., Norton, B., \& Potschin, M. B. (2012). Ethical Considerations in On-Ground Applications of the Ecosystem Services Concept. BioScience, 62(12), 1020-1029. http://doi.org/10.1525/bio.2012.62.12.4

Maes, J., Liquete, C., Teller, A., Erhard, M., Paracchini, M. L., Barredo, J. I., ...\& Lavalle, C. (2016). An indicator framework for assessing ecosystem services in support of the EU Biodiversity Strategy to 2020. Ecosystem Services, 17, 14-23. http://doi.org/10.1016/j.ecoser.2015.10.023

Mansley, E., \& Demšar, U. (2015). Space matters: Geographic variability of electoral turnout determinants in the 2012 London mayoral election. Electoral Studies, 40, 322-334. http://doi.org/10.1016/j.electstud.2015.10.003

Martínez Pastur, G., Peri, P. L., Lencinas, M. V., García-Llorente, M., \& Martín-López, B. (2015). Spatial patterns of cultural ecosystem services provision in Southern Patagonia. Landscape Ecology (on-line) DOI 10.1007/s10980-015-0254-9.

Martín-López, B., Gómez-Baggethun, E., Lomas, P. L., \& Montes, C. (2009). Effects of spatial and temporal scales on cultural services valuation. Journal of Environmental Management, 90(2), 1050-1059. http://doi.org/10.1016/j.jenvman.2008.03.013

Martín-López, B., Iniesta-Arandia, I., García-Llorente, M., Palomo, I., Casado-Arzuaga, I., Amo, D. G. D., ... \& Montes, C. (2012). Uncovering Ecosystem Service Bundles 
through Social Preferences. PLoS ONE, 7(6), e38970.

http://doi.org/10.1371/journal.pone.0038970

Milcu, A. I., Hanspach, J., Abson, D., \& Fischer, J. (2013). Cultural ecosystem services: A literature review and prospects for future research. Ecology and Society, 18(3), 44.

Millennium Ecosystem Assessment (MEA) (2005). Ecosystems and human wellbeing: Current state and trends. Island Press, Washington, USA

Nahuelhual, L., Carmona, A., Lozada, P., Jaramillo, A., \& Aguayo, M. (2013). Mapping recreation and ecotourism as a cultural ecosystem service: An application at the local level in Southern Chile. Applied Geography, 40, 71-82. http://doi.org/10.1016/j.apgeog.2012.12.004

Nakaya, T., Fotheringham, A. S., Brunsdon, C., \& Charlton, M. (2005). Geographically weighted Poisson regression for disease association mapping. Statistics in Medicine, 24(17), 2695-2717. http://doi.org/10.1002/sim.2129

Oteros-Rozas, E., Martín-López, B., González, J. A., Plieninger, T., López, C. A., \& Montes, C. (2014). Socio-cultural valuation of ecosystem services in a transhumance socialecological network. Regional Environmental Change, 14(4), 1269-1289. http://doi.org/10.1007/s10113-013-0571-y

Páez, A., Farber, S., \& Wheeler, D. (2011). A simulation-based study of geographically weighted regression as a method for investigating spatially varying relationships. Environment and Planning A, 43(12), 2992-3010. http://doi.org/10.1068/a44111

Paracchini, M. L., Zulian, G., Kopperoinen, L., Maes, J., Schägner, J. P., Termansen, M., \& Bidoglio, G. (2014). Mapping cultural ecosystem services: A framework to assess the potential for outdoor recreation across the EU. Ecological Indicators, 45, 371-385. http://doi.org/10.1016/j.ecolind.2014.04.018 
Petrosillo, I., Zurlini, G., Corlianò, M. E., Zaccarelli, N., \& Dadamo, M. (2007). Tourist perception of recreational environment and management in a marine protected area. Landscape and Urban Planning, 79(1), 29-37. http://doi.org/10.1016/j.landurbplan.2006.02.017

Phillips, A. (1998). The nature of cultural landscapes - a nature conservation perspective. Landscape Research, 23(1), 21-38. http://doi.org/10.1080/01426399808706523

Plieninger, T., Dijks, S., Oteros-Rozas, E., \& Bieling, C. (2013). Assessing, mapping, and quantifying cultural ecosystem services at community level. Land Use Policy, 33, 118-129. http://doi.org/10.1016/j.landusepol.2012.12.013

Produit, T., Tuia, D., De Morsier, F., \& Golay, F. (2014). Do geographic features impact pictures location shared on the Web? Modeling photographic suitability in the Swiss Alps. In Environmental Multimedia Retrieval (Vol. 1222, pp. 22-29). Glasgow, UK: CEUR-WS.org. Retrieved from http://ceur-ws.org/

Raudsepp-Hearne, C., Peterson, G. D., \& Bennett, E. M. (2010). Ecosystem service bundles for analyzing tradeoffs in diverse landscapes. Proceedings of the National Academy of Sciences, 107(11), 5242-5247. http://doi.org/10.1073/pnas.0907284107

Redon, M., Bergès, L., Cordonnier, T., \& Luque, S. (2014). Effects of increasing landscape heterogeneity on local plant species richness: how much is enough? Landscape Ecology, 29(5), 773-787. http://doi.org/10.1007/s10980-014-0027-x

Refuges.info (2014). Cartes des refuges, sommets et sources/point d'eau dans zone des Alpes, available under a Creative Commons Attribution 2.0 Generic License. Noncommercial license. (accessed 03.12.14)

Richards, D. R., \& Friess, D. A. (2015). A rapid indicator of cultural ecosystem service usage at a fine spatial scale: Content analysis of social media photographs. Ecological Indicators, 53, 187-195. http://doi.org/10.1016/j.ecolind.2015.01.034 
Schaich, H., Bieling, C., \& Plieninger, T. (2010). Linking ecosystem services with cultural landscape research. Gaia-Ecological Perspectives for Science and Society, 19(4), 269277.

Sherrouse, B. C., Clement, J. M., \& Semmens, D. J. (2011). A GIS application for assessing, mapping, and quantifying the social values of ecosystem services. Applied Geography, 31(2), 748-760. http://doi.org/10.1016/j.apgeog.2010.08.002

Singleton, A. (2010). Engaging people for common good. GIS Development, 14 (2), 26-29.

Sun, Y., Fan, H., Helbich, M., \& Zipf, A. (2013). Analyzing Human Activities Through Volunteered Geographic Information: Using Flickr to Analyze Spatial and Temporal Pattern of Tourist Accommodation.

Taylor, J., Czarnowski, K., Sexton, N., \& Flick, S. (1995). The importance of water to Rocky Mountain National Park visitors: An adaptation of visitor-employed photography to natural resource management. Journal of Applied Recreation Research, 20(1), 61-85.

Termansen, M., McClean, C. J., \& Skov-Petersen, H. (2004). Recreational site choice modelling using high-resolution spatial data. Environment and Planning A, 36(6), 1085-1099. http://doi.org/10.1068/a36164

Van Berkel, D. B., \& Verburg, P. H. (2014). Spatial quantification and valuation of cultural ecosystem services in an agricultural landscape. Ecological Indicators, 37, 163-174. http://doi.org/10.1016/j.ecolind.2012.06.025

Vollmer, D., Prescott, M. F., Padawangi, R., Girot, C., \& Grêt-Regamey, A. (2015). Understanding the value of urban riparian corridors: Considerations in planning for cultural services along an Indonesian river. Landscape and Urban Planning, 138, 144154. http://doi.org/10.1016/j.landurbplan.2015.02.011 
Willemen, L., Cottam, A. J., Drakou, E. G., \& Burgess, N. D. (2015). Using Social Media to Measure the Contribution of Red List Species to the Nature-Based Tourism Potential of African Protected Areas. PloS One, 10(6), e0129785.

Wood, S. A., Guerry, A. D., Silver, J. M., \& Lacayo, M. (2013). Using social media to quantify nature-based tourism and recreation. Scientific Reports, 3. http://doi.org/10.1038/srep02976

Zandersen, M., Termansen, M., \& Jensen, F. S. (2007). Evaluating approaches to predict recreation values of new forest sites. Journal of Forest Economics, 13(2-3), 103-128. http://doi.org/10.1016/j.jfe.2007.02.003

Zielstra, D., \& Hochmair, H. H. (2013). Positional accuracy analysis of Flickr and Panoramio images for selected world regions. Journal of Spatial Science, 58(2), 251-273. 


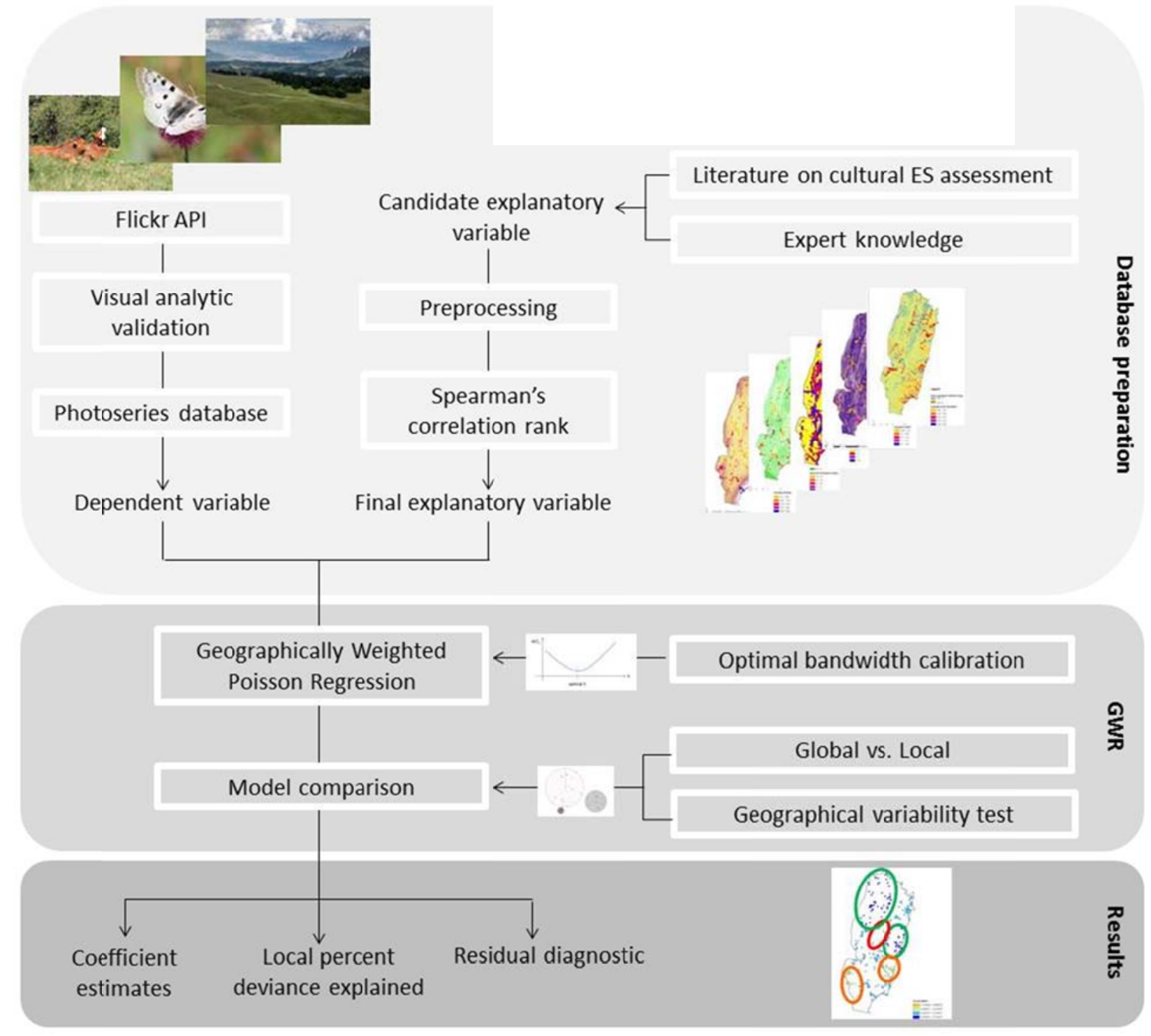

Figure 4. Proposed methodological framework for analysing the actual provision of CES. 

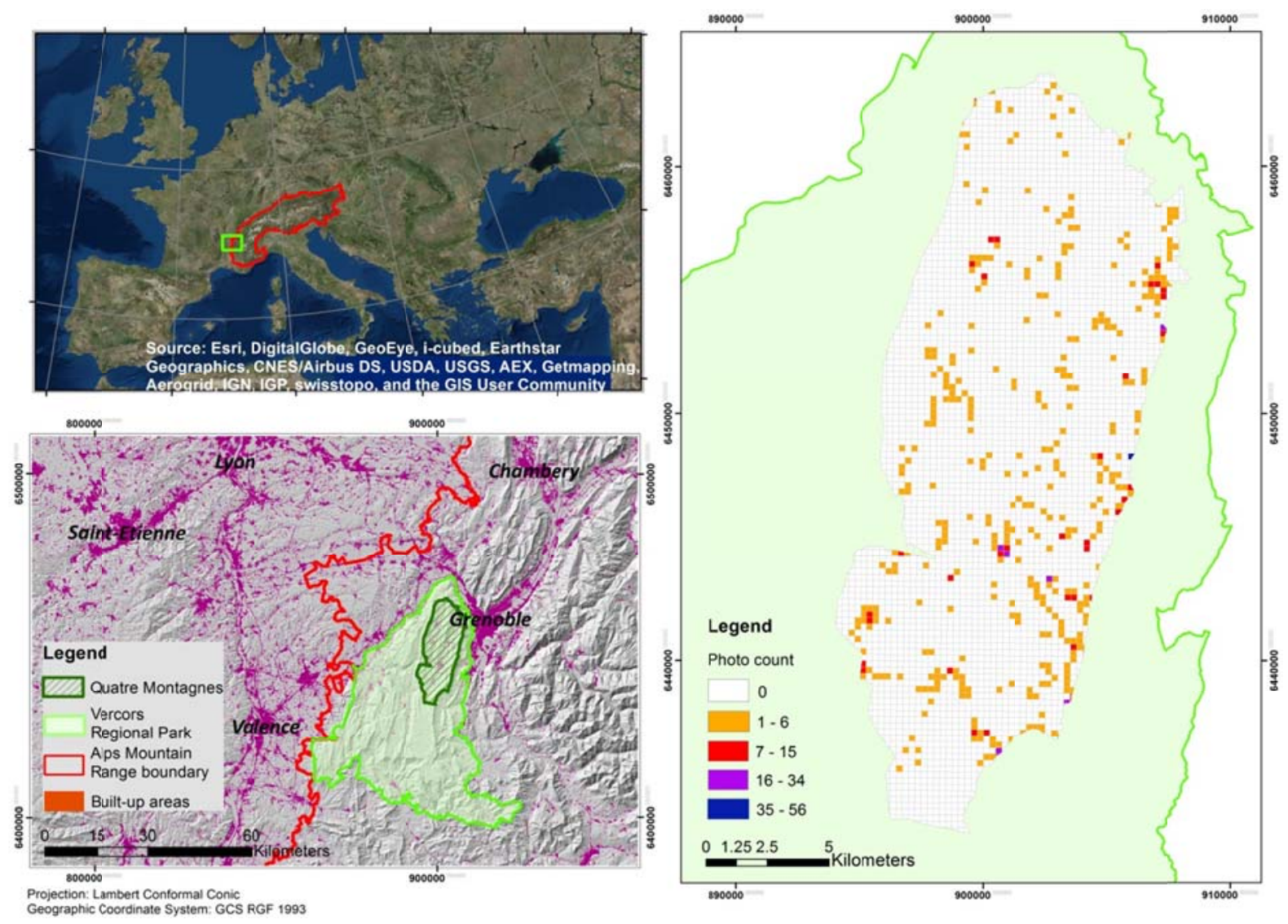

Figure 5. Study area location in the Alpine Mountain Range and Vercor Regional Park (left);

Distribution of Flickr photo counts in Quatre-Montagnes (right). 

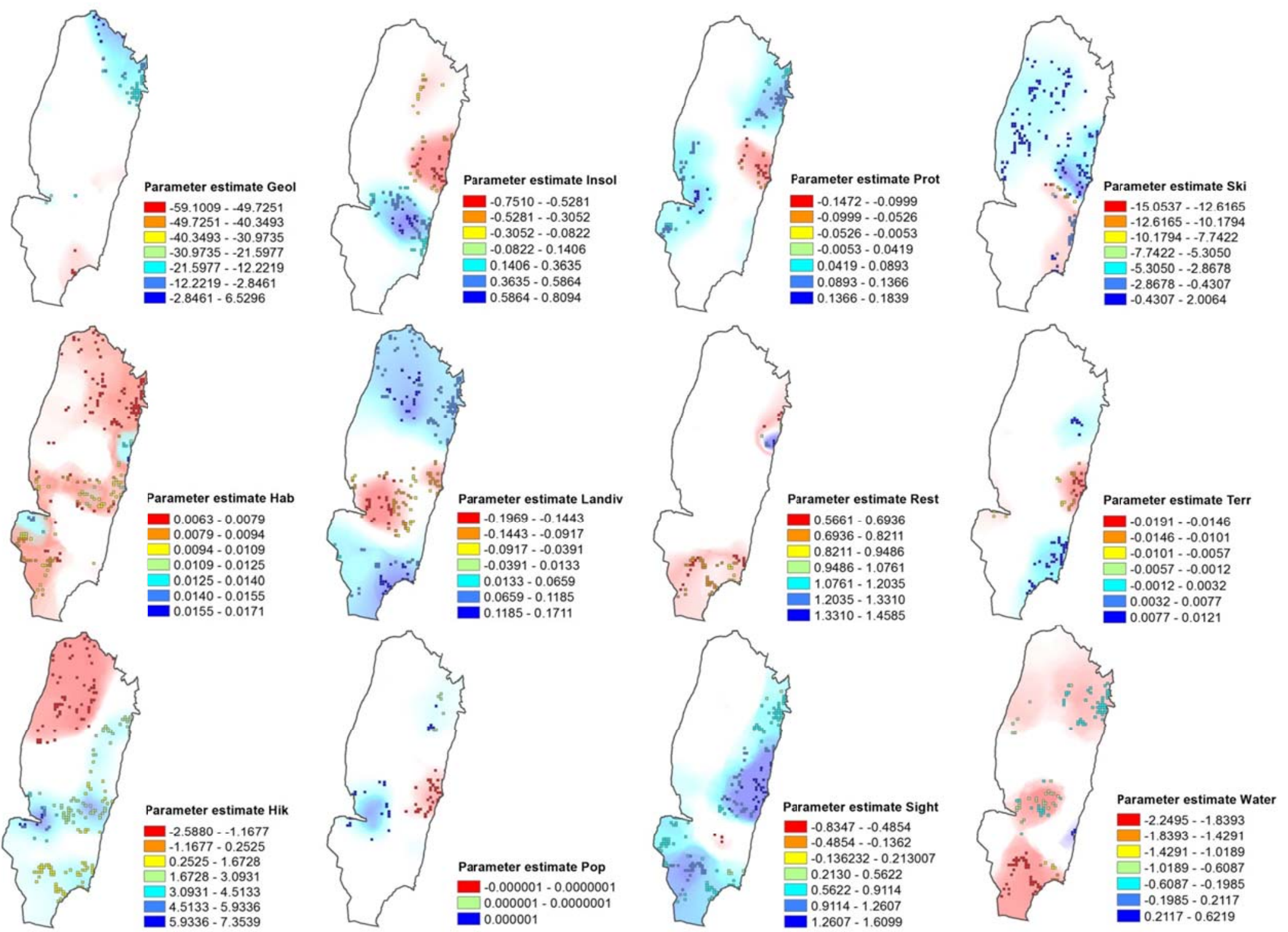

Figure 6. Local parameter estimate surface associated with significance level (areas with non-significant relationships are shown as white). 


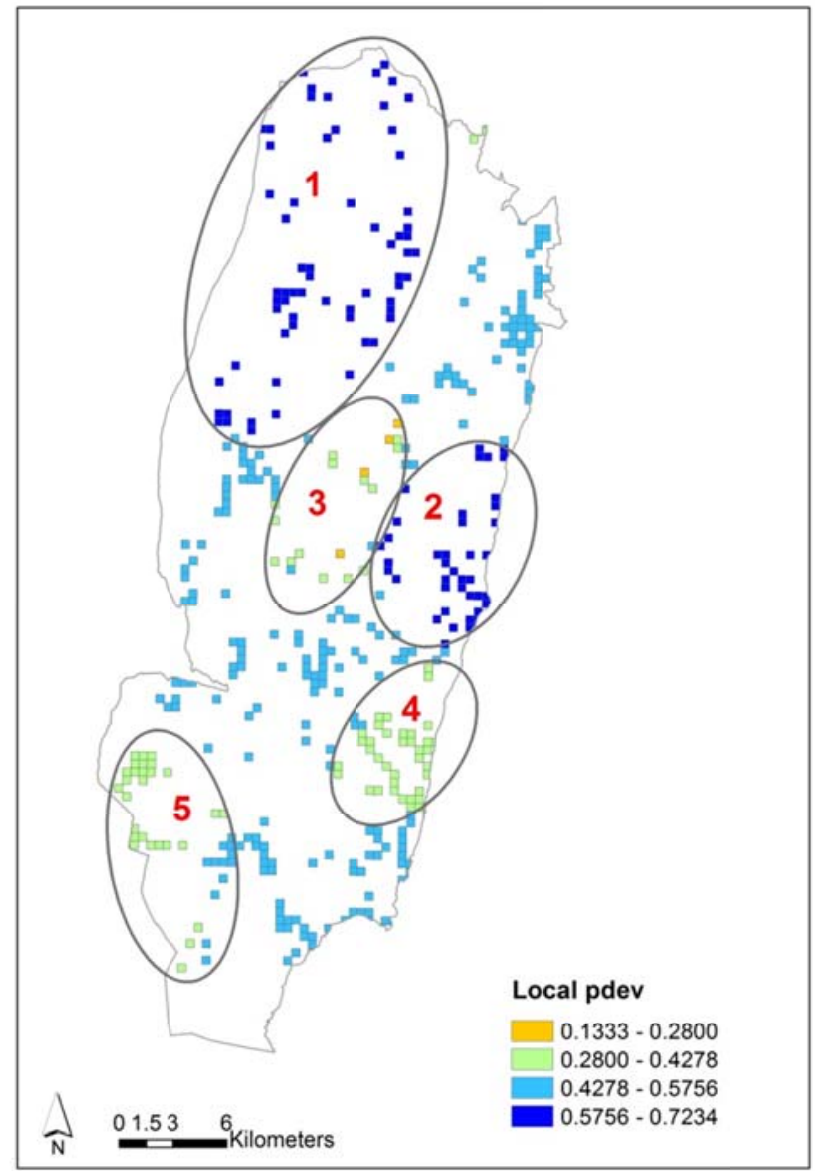

Figure 7. Local percentage of explained deviance. Clusters 1 and 2 represent areas where the percentage of deviance explained is higher than the average; clusters $3,4,5$, represent areas where the percentage of deviance explained is lower than the average. 

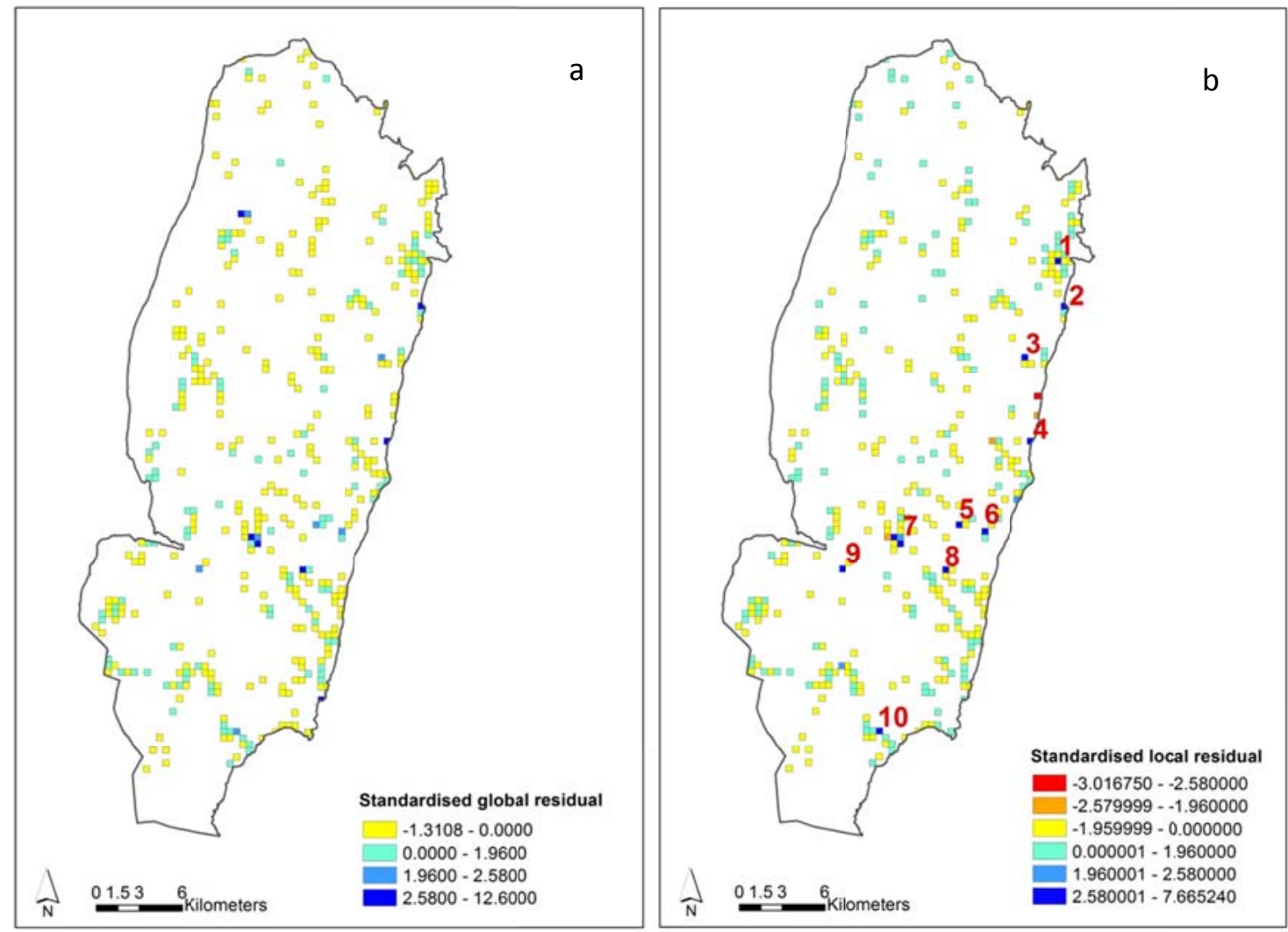

Figure 8. Standardized residuals for global model (a), and local model (b); outliers in the local residuals are indicated with numbers. 
Table 1. Description of the selected independent variables.

\begin{tabular}{|c|c|c|}
\hline Name & Description & Range \\
\hline \multicolumn{3}{|c|}{ Environmental variables } \\
\hline Sight & $\begin{array}{l}\text { Proximity to sighting points, with c value in equation (1) equal to } 100 \mathrm{~m} \text {; } \\
\text { sighting points are represented by summits, peaks, pass, high ridges and mesas } \\
\text { - data source: IGN (2008) }\end{array}$ & $0-1$ \\
\hline Geol & $\begin{array}{l}\text { Proximity to geology interest points, with c value in equation (1) equal to } 50 \mathrm{~m} \text {; } \\
\text { geology interest points are represented by caves, rocks, escarpments - data } \\
\text { source: IGN (2008) }\end{array}$ & $0-1$ \\
\hline Terr & $\begin{array}{l}\text { Average slope (\%) computed according to equation (2) - based on a } 25 \mathrm{~m} \\
\text { resolution Digital Terrain Model (IGN 2009) }\end{array}$ & $0-100$ \\
\hline Alti & $\begin{array}{l}\text { Average altitude (meters) computed according to equation (2) - based on a } \\
25 \mathrm{~m} \text { resolution Digital Terrain Model (IGN 2009) }\end{array}$ & $\begin{array}{l}843- \\
2019\end{array}$ \\
\hline Insol & Annual insolation in $\mathrm{kWh} /\left(\mathrm{m}^{2}\right.$ day $)$, computed according to equation (2) & $0-5$ \\
\hline Water & $\begin{array}{l}\text { Proximity to lakes and streams, with c value in equation (1) equal to } 100 \mathrm{~m}- \\
\text { data source: IGN (2008) }\end{array}$ & $0-1$ \\
\hline Prot & $\begin{array}{l}\text { Protection status given by sum of the protection score assigned to different } \\
\text { protected areas with the following priority: } 1 . \text { Community Habitat }^{1} ; 2 . \mathrm{RBI}^{2} \\
\text { and } \mathrm{ESA}^{3} ; 3 \text {. Natura } 2000^{4} ; 4 . \mathrm{IBAs}^{5} \text { and ZNIEFF}\end{array}$ & $1-13$ \\
\hline $\mathrm{Hab}$ & Vegetation and habitat class: dominant class in a cell. & - \\
\hline Hadiv & Number of different habitat type in a cell & $1-14$ \\
\hline
\end{tabular}

\section{Opportunity setting variables}

Hik Proximity to roads, including forest roads and trails, with c value in equation $\quad 0-1$ (1) equal to 100 - data source: IGN (2008)

Ski Proximity to ski resort, with c value in equation (1) equal to 150 - data source: $0-1$ Irstea (2014)

Rest Proximity to restoration points, with c value in equation (1) equal to 250; $0-1$ restoration points are represented by fountain, refuges and camping sites - data source: Refuges.info (2014).

Settl Proximity to human settlements, with c value in equation (1) equal to $150 \quad 0-1$

Pop Number of people who can reach the cell from the surrounding $100 \mathrm{~km}$ - data 0 source INSEE (2007) - : weighted sum computed according to the following 1056715 formula:

$$
P_{j}=\sum_{k=1}^{-L} \exp \frac{-l_{x}^{2}}{2 c^{2}} * p_{x}
$$

where $P_{j}$ is the total share of population who can reach the cell $j, L$ is maximum travelled distance, $l_{x}$ is the distance of the cell from the origin population cell $x$, calculated as cost function on the road network, $c$ is set at 50000 , and $p_{x}$ is number of people leaving in the $\mathrm{x}$ cell. 
${ }^{1}$ Areas of Community interest based on European Habitats Directive; ${ }^{2}$ Biological Integral Reserve; ${ }^{3}$ Environmentally Sensitive Area; ${ }^{4}$ EUwide network of nature protection area under the 1992 Habitats Directive. Zone of valuable and threatened species and habitats; ${ }^{5}$ Important Bird Areas; ${ }^{6}$ Natural Area of special Ecological, Faunistic or Floristic Interest 
Table 2. Spearman correlation coefficients for global parameters. Variables which were excluded from the model are indicated in bold.

\begin{tabular}{|c|c|c|c|c|c|c|c|c|c|c|c|c|c|}
\hline & Sight & Geol & Water & Hik & Ski & Rest & Settl* & Prot & Terr & Alti* & Insol & Pop & $\mathrm{Hab}$ \\
\hline Sight & 1 & & & & & & & & & & & & \\
\hline Geol & $0.14 *$ & 1 & & & & & & & & & & & \\
\hline Water & $-0.20 *$ & $-0.15^{*}$ & 1 & & & & & & & & & & \\
\hline Hik & -0.06 & 0.02 & $-0.15 *$ & 1 & & & & & & & & & \\
\hline Ski & 0.02 & -0.07 & $-0.10^{*}$ & 0.01 & 1 & & & & & & & & \\
\hline Rest & 0.02 & -0.01 & -0.02 & 0.08 & -0 & 1 & & & & & & & \\
\hline Settl & $-0.50 *$ & $-0.19 *$ & $0.41^{*}$ & -0.60 & 0 & 0.06 & 1 & & & & & & \\
\hline Prot & $0.47 *$ & $0.15^{*}$ & $-0.23 *$ & -0.06 & $-0.2^{*}$ & 0.03 & $-0.53 *$ & 1 & & & & & \\
\hline Terr & $0.60 *$ & $0.10 *$ & $-0.24 *$ & -0.04 & 0.02 & -0.06 & $-0.43 *$ & $0.40^{*}$ & 1 & & & & \\
\hline Alti & $0.55^{*}$ & $0.12 *$ & $-0.57^{*}$ & $0.58^{*}$ & $0.22 *$ & 0.04 & $-0.78 *$ & $0.34 *$ & $0.45^{*}$ & 1 & & & \\
\hline Insol & $-0.20 *$ & $-0.15^{*}$ & -0.03 & 0.04 & $-0.1^{*}$ & 0.08 & 0.06 & $-0.19 *$ & $-0.29 *$ & 0.04 & 1 & & \\
\hline Pop & $-0.40 *$ & $-0.15^{*}$ & $0.44^{*}$ & $-0.10 *$ & $-0.1^{*}$ & 0.01 & $0.71^{*}$ & $-0.38 *$ & $-0.35^{*}$ & $-0.71 *$ & 0.01 & 1 & \\
\hline $\mathrm{Hab}$ & $-0.20 *$ & $-0.17^{*}$ & $0.14^{*}$ & 0.00 & $0.21^{*}$ & 0.00 & $0.27^{*}$ & $-0.48 *$ & $-0.12 *$ & 0.03 & $0.12^{*}$ & $0.20^{*}$ & 1 \\
\hline Hadiv & -0.05 & -0.05 & -0.02 & -0.06 & $0.14^{*}$ & $0.17^{*}$ & $0.23^{*}$ & $-0.14^{*}$ & -0.08 & $-0.11 *$ & -0.05 & $0.22 *$ & $0.13 *$ \\
\hline
\end{tabular}

Numbers in bold font represent absolute values higher than 0.7

*Correlation significant at the 0.05 level 
Table 3. Global regression results.

\begin{tabular}{lcccc}
\hline Variable & Estimate & St.Error & $\mathbf{z}($ Est/SE) & Exp(Est) \\
\cline { 1 - 2 } Intercept & -2.7745 & 0.4228 & -6.5616 & 0.0624 \\
Sight & 0.5926 & 0.0939 & $\mathbf{6 . 3 1 2 8}$ & 1.8088 \\
Geol & -0.0072 & 0.3075 & -0.0236 & 0.9927 \\
Water & -0.3503 & 0.0987 & -3.5499 & 0.7045 \\
Hik & 0.4837 & 0.1781 & 2.7157 & 1.6221 \\
Ski & 0.1209 & 0.0848 & 1.4263 & 1.1286 \\
Rest & 0.1392 & 0.1201 & 1.1593 & 1.1494 \\
Prot & 0.0049 & 0.0117 & 0.4196 & 1.0049 \\
Terr & 0.0025 & 0.0015 & 1.6992 & 1.0025 \\
Insol & -0.0558 & 0.0359 & -1.5519 & 0.9457 \\
Pop & 0.0000 & 0.0000 & 0.1695 & 1.0000 \\
Hab & 0.0094 & 0.0011 & $\mathbf{8 . 7 3 1 2}$ & 1.0094 \\
Landiv & 0.0199 & 0.0123 & 1.6142 & 1.0201 \\
\hline
\end{tabular}

Numbers in bold font represent scores higher than the critical value at $95 \%$ confidence interval $(\mathrm{z}<-1.96$ or $\mathrm{z}>1.96)$. 
Table 4. Analysis of local parameter significance for each cluster.

\begin{tabular}{lllllll}
\hline & & Cluster & Cluster & Cluster & Cluster & Other \\
& Cluster 1 & 2 & 3 & 4 & 5 & \\
\hline Sight & - & ++++ & - & + & +++ & ++ \\
Geol & + & - & - & - & - & + \\
Water & + & - & - & + & + & ++ \\
Hik & ++++ & + & - & + & + & +++ \\
Ski & +++ & +++ & + & + & - & + \\
Rest & - & + & - & - & + & + \\
Prot & - & +++ & - & - & + & + \\
Terr & - & +++ & - & + & - & + \\
Insol & + & ++++ & + & +++ & - & + \\
Pop & - & +++ & + & + & - & + \\
Hab & +++ & +++ & + & + & +++ & ++ \\
Hadiv & +++ & +++ & + & + & + & +++ \\
\hline
\end{tabular}

$++++=$ significant everywhere $+++=$ significant in more than $50 \%$ of cells; $++=$ significant in $50 \%$ of cells; $+=$ significant in less than $50 \%$ of cells; $-=$ not significant 
1 Table 5 Standardized residuals autocorrelation.

\begin{tabular}{lll}
\hline & Global residual & Local residuals \\
\hline Moran's Index & 0.0460 & -0.0158 \\
z-score & 1.9167 & -0.4975 \\
p-value & 0.0553 & 0.6188 \\
\hline
\end{tabular}

2

3

4 